\title{
STUDY ON THE ROLE OF SULPHAMETHOXYPYRIDAZINE (ORAL) IN TRACHOMA CONTROL*
}

\author{
BY \\ U. C. GUPTA \\ National Trachoma Control Programme, Government of India, Aligarh
}

\section{Introduction}

Trachoma has a world-wide distribution. It has been estimated that over 400 million people throughout the world are infected with trachoma. Trachoma and associated infections present a major public health problem in India, particularly in the northern and north-western states. Its effects frequently create serious economic problems; not infrequently it produces total blindness. Despite the fact that the infection can be controlled and cured with various remedies, studies are still being conducted in various parts of the world to determine the most economical and effective remedy for mass control of the infection.

Among the several anti-infective agents used in trachoma are the tetracyclines and sulphonamides. The usual sulphonamides, however, have the disadvantage of having to be given several times a day, making mass treatment and observation very difficult, as doses are often not taken. To overcome this difficulty, the longacting sulphonamides were used in the treatment of trachoma. One of these longacting sulphonamides, sulphamethoxypyridazine (Lederkyn-Lederle), has been used with encouraging results.

Several studies confirm the efficacy of sulphamethoxypyridazine in trachoma. These studies have been made with both the oral and oral or parenteral forms of sulphamethoxypyridazine. In these studies two different schedules of oral dosage are used. Bietti (1963), who used the intermittent method as the method of choice in mass treatment campaigns, obtained a cure rate of 70 per cent. with doses of $80 \mathrm{mg}$. per kg. body-weight every 7 or every 10 days. The second study, by Mitsui, Konishi, Kinouchi, and Miki (1964), was a more or less continuous method of administering one $0.5 \mathrm{~g}$. tablet of sulphamethoxypyridazine daily, regardless of the patient's weight, during four 10-day courses, each of the four courses being separated from the other by an interval of 5 days, during which no treatment was given (total of 40 tablets). Using this method, Mitsui and others (1964) obtained a 70 per cent. cure rate. Mann (1960) has also studied the effect of sulphamethoxypyridazine on trachoma.

The results of these investigators prompted us to study the effects of sulphamethoxypyridazine given orally in trachoma. The special feature of this long-

\footnotetext{
* Received for publication April 5, 1965.
} 
acting sulphonamide is that it is a low-dose sulphonamide producing high, longlasting blood levels, and the slow excretion rate makes crystalluria and haematuria exceptionally rare.

\section{Area}

\section{Investigation}

As a part of the therapeutic trials carried out by the Trachoma Control Pilot Project-India (Indian Council of Medical Research; now the National Trachoma Control Programme, Government of India), limited and control studies were undertaken in the district of Aligarh in 1962 and 1963. One village (Nagla Loka), with a population of about 440 people, was selected for treatment trials, and another village (Gopalpur), with a population of about 607 , was taken as control. The two villages selected were considered identical as to the prevalence of infection, socioeconomic factors, cultural strata, and geographical location.

\section{Coverage}

Seventy-nine children in the treated village and 109 in the control village, all in the age-group 0-9 years, were taken for the studies in the programme, and treatment was provided for all children of this age-group in the villages. (Tables I and II.)

TABLE I

Children examined at the Initial and Final Examinations in Treated and Control Villages

\begin{tabular}{l|c|c|c|c}
\hline & \multicolumn{2}{|c|}{ Treated Village } & \multicolumn{2}{c}{ Control Village } \\
\cline { 2 - 5 } & No. & $\begin{array}{c}\text { Percentage of } \\
\text { total initially } \\
\text { examined }\end{array}$ & No. & $\begin{array}{c}\text { Percentage of } \\
\text { number initially } \\
\text { examined }\end{array}$ \\
\hline $\begin{array}{c}\text { Total children initially } \\
\text { examined }\end{array}$ & 79 & 100.00 & 109 & $100 \cdot 0$ \\
\hline $\begin{array}{c}\text { Children absent at final } \\
\text { examination }\end{array}$ & 13 & 16.5 & 26 & 23.9 \\
\hline $\begin{array}{c}\text { Children examined at final } \\
\text { examination }\end{array}$ & 66 & 83.5 & 83 & $76 \cdot 1$ \\
\hline
\end{tabular}

TABLE II

Age Structure of the Child Population in Treated and Control Villages

\begin{tabular}{c|c|c}
\hline Age Groups in Years & Treated Village & Control Village \\
\hline $0-1$ & 9 & 7 \\
$2-4$ & 22 & 39 \\
$5-9$ & 48 & 63 \\
\hline Total & 79 & 109 \\
\hline
\end{tabular}




\section{Methodology}

All children under 10 years of age in the two villages taken for trials were examined during August and September, 1962, and the findings of trachoma were recorded on W.H.O./U.N.I.C.E.F. individual record cards. At the same time the children of the treatment village were also weighed and their weights recorded on the cards.

The drug under trial was sulphamethoxypyridazine in syrup form (Lederle). The treatment schedule consisted of two doses a week repeated every fourth week for a period of six months. The six months selected for trial were September, October, November, and March, April, May-the period when epidemic bacterial conjunctivitis is rife among the children of this part of the country. The interval between the two doses within a week was 4 days, i.e., if a dose was given on the first day, the second was given on the fifth. Since the dose of the medicine under trial was to be calculated on the basis of the weight of the children, the children were grouped into three major categories according to the weights recorded at initial examination:

Up to 1 year-range of weight- $15 \mathrm{lb}$.

Up to 3 years-range of weight- $-15-25 \mathrm{lb}$.

Up to 9 years-range of weight- $25-50 \mathrm{lb}$.

\section{Dosage Schedule}

Each teaspoonful of the syrup (5 ml.) consisted of $250 \mathrm{mg}$. of $N^{\prime}$ acetyl-3-sulphanimido-6-methoxypyridazine. Children up to 1 year of age were given a quarter of a teaspoonful, up to 3 years, half a teaspoonful, and above that age-group one teaspoonful.

The drug was given to the children by the field-worker appointed for the purpose. The field-worker would measure the dose from the bottle and give it to the children using a spoon provided for the purpose. The medicine was taken by the children in the presence of the field-worker.

\section{Dates for giving the Medicine}

$\begin{array}{ll}\text { September } 11 \text { and 15, 1962 } & \text { March } 19 \text { and 23, } 1963 \\ \text { October 9 and 13,1962 } & \text { April } 16 \text { and 20, } 1963 \\ \text { November } 7 \text { and 11, 1962 } & \text { May } 16 \text { and 20, } 1963\end{array}$

In the control village only a placebo was given. Lessons in health education were given in both the villages throughout the treatment programme.

\section{Evaluation}

The initial examination was conducted as follows:

Treatment village, on August 29 and September 4, 1962.

Control village, on September 11, 18, and 23, 1962.

\section{Re-examination}

Treatment village, on July 19, 1963.

Control village, on July 1, 1963. 


\section{Findings}

The data collected at the initial and final examinations are given in Table III.

Out of 79 children examined at the initial examination in the treated village, total trachoma (trachoma I-IV) was noted in 78.5 per cent. Of this, 68.4 per cent. represented active trachoma (trachoma I-III). In the control village 109 children were examined at the initial examination and total trachoma (trachoma I-IV) was noted in 73.4 per cent. and active trachoma (trachoma I-III) in 64.2 per cent.

At the final examination, which was conducted six to eight weeks after the completion of the treatment, only 66 children in the treated village and 83 children in the control village could be followed up. In the treated village, total trachoma (trachoma I-IV) was noted in 83.3 per cent. and active trachoma in 36.4 per cent., while in the control village figures for total trachoma were 86.7 per cent. and active trachoma $65 \cdot 1$ per cent.

TABLE III

Prevalence of Trachoma by Stages at Initial and Final Examinations in Treated and CONTROL Villages

\begin{tabular}{|c|c|c|c|c|c|c|c|c|}
\hline \multirow{3}{*}{$\begin{array}{l}\text { Trachoma } \\
\text { Stages }\end{array}$} & \multicolumn{4}{|c|}{ Treated Village } & \multicolumn{4}{|c|}{ Control Village } \\
\hline & \multicolumn{2}{|c|}{ Initial Examination } & \multicolumn{2}{|c|}{ Final Examination } & \multicolumn{2}{|c|}{ Initial Examination } & \multicolumn{2}{|c|}{ Final Examination } \\
\hline & No. & Per cent. & No. & Per cent. & No. & Per cent. & No. & Per cent. \\
\hline 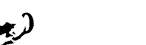 & 17 & $21 \cdot 5$ & 11 & $16 \cdot 7$ & 28 & $25 \cdot 7$ & 11 & $13 \cdot 2$ \\
\hline Doubtful & - & - & - & - & 1 & 0.9 & - & - \\
\hline I & 20 & $25 \cdot 3$ & 7 & $10 \cdot 6$ & 20 & $18 \cdot 3$ & 10 & $12 \cdot 0$ \\
\hline II & 11 & 13.9 & 8 & $12 \cdot 1$ & 14 & $12 \cdot 8$ & 17 & $20 \cdot 5$ \\
\hline III & 23 & $29 \cdot 1$ & 9 & 13.6 & 36 & 33.0 & 27 & $32 \cdot 5$ \\
\hline I - III & 54 & $68 \cdot 4$ & 24 & $36 \cdot 4$ & 70 & $64 \cdot 2$ & 54 & $65 \cdot 1$ \\
\hline IV & 8 & $10 \cdot 1$ & 31 & $47 \cdot 0$ & 10 & $9 \cdot 2$ & 18 & $21 \cdot 7$ \\
\hline I - IV & 62 & $78 \cdot 5$ & 55 & $83 \cdot 3$ & 80 & $73 \cdot 4$ & 72 & $86 \cdot 7$ \\
\hline Total & 79 & $100 \cdot 0$ & 66 & $100 \cdot 0$ & 109 & $100 \cdot 0$ & 83 & $100 \cdot 0$ \\
\hline
\end{tabular}

\section{Discussion}

As a result of the treatment the active trachoma in the treated village was reduced from 68.4 per cent. to 36.4 per cent. In the control village the corresponding figures were $64 \cdot 2$ per cent. at the initial examination and $65 \cdot 1$ per cent. at the final examination.

Effect of Treatment on Different Stages of Trachoma in Children who were followed up until the Final Examination

Trachoma I.-In the treated village the 15 cases noted were reduced to only 5 after the treatment. Two cases were not affected by treatment and progressed to trachoma II, and the remaining 8 were noted to have progressed to trachoma IV. In the control village, out of 17 children in this trachoma group at the initial examination 5 remained as trachoma I, 6 progressed to trachoma II, 4 had signs of trachoma III, and 2 were healed. 
Thus it will be noted that 53.3 per cent. of cases progressed to the trachoma IV stage in the treated group, as against 11.8 per cent. in the control group (Table IV).

Trachoma II.-In the treated village, out of 10 children at this stage of trachoma at the initial examination, 5 remained as trachoma II and 4 showed some signs of progress towards healing. Only 1 case was noted to have progressed to trachoma IV. In the control village, out of 12 children, 10 showed no change of the stage of trachoma and the remaining 2 progressed to trachoma III.

In this group it will be noted that about 50 per cent. of the children showed signs of healing while in the control village only 16.7 per cent. did (Table IV).

Trachoma III.-In the treated village, clinical findings remained unchanged in only 4 out of 20 children and 16 progressed to trachoma IV, while in the control village only 10 out of 28 progressed to trachoma IV.

Thus in this stage the change-over from trachoma III to trachoma IV was 80 per cent. in the treated group as against 35.7 per cent. in the control village.

From the active stages (trachoma I-III) 55.6 per cent. in the treated village and 21.1 per cent. in the control village progressed to the clinical stage of trachoma IV (Table IV). This difference in the results may be ascribed to the efficacy of the drug used for treatment.

As for the prophylactic role played by the drug as observed in children who were initially free from trachoma, it was noted that in the treated village, only 3 out of 14 children caught the infection (21.4 per cent.) as against 7 out of 18 children in the control village-a percentage of 38.9 (Table IV). Amongst 7 healed cases of trachoma noted at the initial examination in both the treated and control villages, only 2 in the treated village and 3 in the control village were noted to have been re-infected (Table IV).

\section{Conclusions}

The studies undertaken, though limited, were well controlled. Sulphamethoxypyridazine given orally in syrup form gave significant results in the treatment of trachoma. The significance of this study lies in the fact that the age-groups studied included children of pre-school age. The syrup form of the drug was convenient to administer and was well received. It did not give rise to any untoward symptoms. We admit that the dosage used is lower than that employed by Bietti (1963) and Mitsui and others (1964), and that the duration of administration of sulphamethoxypyridazine was less. However, this study was undertaken to discover its suitability in relation to a mass control programme where constant medical supervision would not be possible and workers would have to depend on the patient himself taking the medication. It is recommended that further trials, adopting different schedules of posology in different regions, should be undertaken.

In addition to the effect on trachoma infection it was noted that the drug was active against the other general systemic infections like furunculosis, the common cold, bronchitis, minor infective fevers, etc.

Close medical supervision is essential in the administration of this drug. Its usefulness, therefore, appears to be limited in a mass control programme which adopts a blanket treatment schedule in such a country as India, where trachoma prevalence is as high as $79 \cdot 1$ per cent. 
TABLE IV

Response to Treatment in Various Stages of Trachoma compared with Control

VILLAGE

\begin{tabular}{|c|c|c|c|c|c|c|c|c|c|}
\hline \multirow{3}{*}{$\begin{array}{c}\text { Trachoma Stages } \\
\text { at Initial } \\
\text { Examination }\end{array}$} & \multicolumn{9}{|c|}{ At Final Examination } \\
\hline & \multicolumn{9}{|c|}{ Treated Village } \\
\hline & $\begin{array}{c}\text { Total } \\
\text { children } \\
\text { examined }\end{array}$ & 0 & $\begin{array}{l}\text { Doubt- } \\
\text { ful }\end{array}$ & I & II & III & I-III & IV & I-IV \\
\hline 0 & 14 & 11 & - & 1 & 1 & - & 2 & 1 & 3 \\
\hline Doubtful & - & - & - & - & - & - & - & - & - \\
\hline I & 15 & - & - & 5 & 2 & - & 7 & 8 & 15 \\
\hline II & 10 & - & - & - & 5 & 4 & 9 & 1 & 10 \\
\hline III & 20 & - & - & - & - & 4 & 4 & 16 & 20 \\
\hline I-III & $\begin{array}{c}45 \\
100 \cdot 0 \% \\
\end{array}$ & - & - & $\begin{array}{c}5 \\
11 \cdot 1 \%\end{array}$ & $15.6 \%$ & $\begin{array}{c}8 \\
17.8 \% \\
\end{array}$ & $\begin{array}{c}20 \\
44 \cdot 4 \%\end{array}$ & $\begin{array}{c}25 \\
55 \cdot 6 \%\end{array}$ & $\begin{array}{c}45 \\
100 \cdot 0 \%\end{array}$ \\
\hline IV & 7 & - & - & - & - & 2 & 2 & 5 & 7 \\
\hline I-IV & $\begin{array}{c}52 \\
100 \cdot 0 \% \\
\end{array}$ & - & - & $\begin{array}{c}5 \\
9.6 \% \\
\end{array}$ & $\begin{array}{c}7 \\
13.5 \% \\
\end{array}$ & $\begin{array}{c}10 \\
19 \cdot 2 \%\end{array}$ & $\begin{array}{l}22 \\
42 \cdot 3 \%\end{array}$ & $\begin{array}{c}30 \\
57 \cdot 7 \%\end{array}$ & $\begin{array}{c}52 \\
100.0 \%\end{array}$ \\
\hline \multirow[t]{2}{*}{$\begin{array}{l}\text { Total children } \\
\text { examined }\end{array}$} & $\begin{array}{c}66 \\
100 \cdot 0 \%\end{array}$ & $\begin{array}{c}11 \\
16 \cdot 7 \%\end{array}$ & - & $\begin{array}{c}6 \\
9 \cdot 1 \%\end{array}$ & $12 \cdot 1 \%$ & $\begin{array}{c}10 \\
15 \cdot 2 \%\end{array}$ & $\begin{array}{c}24 \\
36 \cdot 4 \%\end{array}$ & $\begin{array}{c}31 \\
47 \cdot 0 \%\end{array}$ & $\begin{array}{c}55 \\
83 \cdot 3 \%\end{array}$ \\
\hline & \multicolumn{9}{|c|}{ Control Village } \\
\hline 0 & 18 & 11 & - & 3 & 1 & 1 & 5 & 2 & 7 \\
\hline Doubtful & 1 & - & - & 1 & - & - & 1 & - & 1 \\
\hline$I$ & 17 & - & - & 5 & 6 & 4 & 15 & 2 & 17 \\
\hline II & 12 & - & - & - & 10 & 2 & 12 & - & 12 \\
\hline III & 28 & - & - & - & - & 18 & 18 & 10 & 28 \\
\hline I-III & $\begin{array}{c}57 \\
100 \cdot 0 \% \\
\end{array}$ & - & - & $\begin{array}{c}5 \\
8 \cdot 7 \% \\
\end{array}$ & $\begin{array}{c}16 \\
28 \cdot 1 \% \\
\end{array}$ & $\begin{array}{c}24 \\
42 \cdot 1 \% \\
\end{array}$ & $\begin{array}{c}45 \\
78.9 \% \\
\end{array}$ & $\begin{array}{c}12 \\
21 \cdot 1 \%\end{array}$ & $\begin{array}{c}57 \\
100.0 \%\end{array}$ \\
\hline IV & 7 & - & - & - & - & 3 & 3 & 4 & 7 \\
\hline I-IV & $100 \cdot 0 \%$ & - & - & $\begin{array}{c}5 \\
7 \cdot 8 \%\end{array}$ & $\begin{array}{c}16 \\
25 \cdot 0 \%\end{array}$ & $\begin{array}{l}27 \\
42 \cdot 2 \%\end{array}$ & $\begin{array}{c}48 \\
75 \cdot 0 \% \\
\end{array}$ & $\begin{array}{c}16 \\
25 \cdot 0 \%\end{array}$ & $\begin{array}{c}64 \\
100 \cdot 0 \%\end{array}$ \\
\hline $\begin{array}{l}\text { Total children } \\
\text { examined }\end{array}$ & $\begin{array}{c}83 \\
100 \cdot 0 \%\end{array}$ & $\begin{array}{c}11 \\
13 \cdot 2 \%\end{array}$ & - & $\begin{array}{c}9 \\
10.8 \%\end{array}$ & $\begin{array}{c}17 \\
20 \cdot 5 \%\end{array}$ & $\begin{array}{c}28 \\
33 \cdot 7 \%\end{array}$ & $\begin{array}{c}54 \\
65 \cdot 1 \%\end{array}$ & $\begin{array}{c}18 \\
21 \cdot 7 \%\end{array}$ & $\begin{array}{c}72 \\
86 \cdot 7 \%\end{array}$ \\
\hline
\end{tabular}

The author is grateful to Lederle Laboratories Division, Cyanamid of India Ltd., for the liberal supply of sulphamethoxypyridazine (Lederkyn) for field trials. The assistance provided by the staff of the Trachoma Control Pilot Project - India (Indian Council of Medical Research; now the National Trachoma Control Programme, Government of India), Aligarh, is acknowledged with appreciation and thanks.

\section{REFERENCES}

BietTi, G. B. (1963). Bull. Wld Hlth Org., 28, 395.

ManN, I. (1960). Brit. J. Ophthal., 44, 324.

Mitsui, Y., Konishi, K., Kinouchi, T., and Miki, T. (1964). Amer. J. trop. Med. Hyg., 13, 488. 